\title{
ANALISIS KINERJA KEUANGAN PERUSAHAAN MAKANAN DAN MINUMAN YANG TERDAFTAR DI BURSA EFEK INDONESIA (BEI) PADA MASA KABINET INDONESIA BERSATU JILID I DAN II
}

\author{
Galih Wisnu Wardhana ${ }^{1}$ \\ Anton Respati Pamungkas ${ }^{2}$ \\ Imam Nazarudin Latif ${ }^{3}$ \\ ${ }^{1}$ Akademi Teknologi Adhi Unggul Bhirawa (AUB) Surakarta \\ gwisnu1@gmail.com \\ ${ }^{2}$ STMIK AUB Surakarta \\ anton18@stmik-aub.ac.id \\ ${ }^{3}$ University of 17 Agustus 1945 Samarinda \\ imamlatif5@gmail.com
}

\begin{abstract}
Financial performance is the determination of certain measures that can measure the success of a company in generating profits. Efficient company performance, one of wich can be seen from the increase in profits earned by the company, so that in the end will bring a positive impact on government revenue from the taxation sector. The purpose of this study was to obtain empirical evidence about the efficiency of food and beverage companies on the IDX during the United Indonesia Cabinet I and II.

The population of this research is the manufacturing companies since 2005 -201 which amounted to 19 companies, after the purpose of purposive sampling method with the aim of getting samples in accordance with the research objectives, there are 17 companies that fit the criteria set for the sample.

The results of this study prove that there are significant differences for the variables $C R, D E R, N P M, R O A$ and EPS, food and beverage companies in the period of KIB I and $K I B I I$, this means that company managers and investors generally responded in the governance period of KIB I and KIB II

Keywords: Financial Ratio, Financial Management United Indonesia Cabinet.

\section{PENDAHULUAN}

Pemerintah mengharapkan bahwa dengan adanya Kabinet Indonesia Bersaru tersebut kinerja perpajakan akan semakin baik, sehingga dengan semakin membaiknya kinerja

perpajakan akan membawa dampak yang positif terhadap penerimaan pemerintah dari sektor perpajakan. Analisis kinerja perusahaan mencakup analisis rasio keuangan, dengan rasiorasio keuangan tersebut kondisi dan
\end{abstract}


posisi keuangan suatu perusahaan dapat diketahui. Rasio keuangan merupakan persentase sebagai hasil perbandingan antara pos perkiraan tertentu yang tercantum dalam laporan keuangan suatu perusahaan, yang terdiri dari neraca dan laba rugi. Hal tersebut diharapkan dapat membantu dalam menilai prestasi manajemen masa lalu dan prospeknya di masa yang akan datang (Mariwan dan Arifin, 2005).

Melalui rasio keuangan, dapat digunakan sebagai perbandingan. Pertama, bisa membandingkan rasio keuangan suatu perusahaan dari waktu ke waktu untuk mengamati kecenderungan (trend) yang sedang terjadi. Kedua, bisa membandingkan rasio keuangan perusahaan dengan perusahaan lain yang masih bergerak pada industri yang relatif sama pada periode tertentu. Salah satu pihak yang berkepentingan dengan informasi rasio keuangan adalah para investor dan calon investor atas perusahaanperusahaan yang go public. Dengan informasi itu, mereka dapat mengetahui kinerja perusahaan-perusahaan tersebut. Investor berharap mendapatkan hasil atau yields atas investasi yang mereka lakukan. Hasil yang diharapkan oleh para investor terdiri atas dua macam, yaitu dividen dan selisih harga atau capital gain.

Berdasarkan uraian di atas, maka penelitian ini diberi judul "Analisis Kinerja Keuangan Perusahaan Makanan dan Minuman yang Terdaftar di Bursa Efek Indonesia (BEI) Pada masa Kabinet Indonesia

\section{Bersatu I dan II"}

Berdasarkan uraian latar belakang diatas, maka dapat dirumuskan masalah sebagai berikut :

1. Apakah terdapat perbedaan Current Ratio (CR), Debt to Equity Ratio (DER), Debt to Asset Ratio (DAR), Gross Profit Margin (GPM), Operating Profit Margin (OPM), Net Profit Margin (NPM), Quick Asset to Inventory (QAI), Total Asset Turnover (TAT), Return on Asset (ROA), Return on Equity (ROE), dan Earning per Share (EPS) pada perusahaan makanan dan minuman di BEI pada masa Kabinet Indonesia Bersatu I dan II?

\section{KERANGKA TEORITIS}

\section{Kabinet Indonesia Bersatu}

Kabinet Indonesia Bersatu adalah kabinet pemerintahan Indonesia pimpinan Presiden Susilo Bambang 
Yudhoyono dan Wakil Presiden Muhammad Jusuf Kalla. Kabinet ini dibentuk pada 21 Oktober 2004 dan masa baktinya berakhir pada tahun 2009. Pada 5 Desember 2005, Presiden Yudhoyono melakukan perombakan kabinet untuk pertama kalinya, dan setelah melakukan evaluasi lebih lanjut atas kinerja para menterinya, Presiden melakukan perombakan kedua pada 7 Mei 2007.

Kabinet Indonesia Bersatu II adalah kabinet pemerintahan Indonesia pimpinan Presiden Susilo Bambang Yudhoyono dan Wakil Presiden Boediono. Susunan kabinet ini berasal dari usulan partai politik pengusul pasangan SBY-Boediono pada Pilpres 2009 yang mendapatkan kursi di DPR (Partai Demokrat, PKS, PAN, PPP, dan PKB) ditambah Partai Golkar yang bergabung setelahnya, tim sukses pasangan SBY-Boediono pada Pilpres 2009, serta kalangan profesional. Susunan Kabinet Indonesia Bersatu II diumumkan oleh Presiden SBY pada 21 Oktober 2009 dan dilantik sehari setelahnya. Pada 19 Mei 2010, Presiden SBY mengumumkan pergantian Menteri Keuangan. Pada tanggal 18 Oktober 2011, Presiden SBY mengumumkan perombakan Kabinet Indonesia Bersatu II, beberapa wajah baru masuk ke dalam kabinet dan beberapa menteri lainnya bergeser jabatan di dalam kabinet. ${ }^{[}$Pada tanggal 13 Juni 2012, Presiden SBY mengumumkan pergantian Menteri Kesehatan dimana pejabat sebelumnya telah meninggal dunia.

\section{Analisis Laporan Keuangan}

\section{Laporan Keuangan}

Laporan keuangan pada dasarnya adalah hasil dari proses akuntansi yang dapat digunakan sebagai alat untuk berkomunikasi antara data keuangan atau aktivitas suatu perusahaan dengan pihak-pihak yang berkepentingan dengan da Pengertian Laporan Keuangan

Laporan keuangan pada dasarnya adalah hasil dari proses akuntansi yang dapat digunakan sebagai alat untuk berkomunikasi antara data keuangan atau aktivitas suatu perusahaan dengan pihak-pihak yang berkepentingan dengan data atau ektivitas perusahaan tersebut (Munawir, 2000:2). Laporan keuangan (financial statement) memberikan ikhtisar mengenai keadaan finansial suatu perusahaan, dimana neraca (balance sheet) mencerminkan 
nilai aktiva, utang dan modal sendiri pada suatu saat tertentu, dan laporan laba rugi (income statement) mencerminkan hasil-hasil yang dicapai selama suatu periode tertentu biasanya meliputi periode satu tahun (Bambang Riyanto, 1997:25).

Menurut SAK dalam bagian kerangka dasar penyusunan dan penyajian laporan keuangan mendefinisikan bahwa laporan keuangan meliputi neraca, laporan laba rugi, laporan perubahan posisi keuangan (yang dapat disajikan dalam berbagai cara, misalnya sebagai laporan arus kas atau laporan arus dana) dan catatan atas laporan keuangan, laporan lain serta materi penjelasan yang merupakan bagian integral dari laporan keuangan (Robert Ang 1997).

\section{Rasio Keuangan dan Manfaatnya}

Rasio keuangan dapat digunakan sebagai pembanding risiko dan tingkat imbal balik hasil dari perusahaan perusahaan untuk membantu investor dan kreditor dalam membuat keputusan investasi dan kredit yang baik (White et al., 2003). Menurut White et al ada empat kategori rasio yang digunakan yaitu sebagai berikut.
1. Analisis likuiditas yang digunakan untuk mengukur kecukupan sumber kas suatu perusahaan dalam memenuhi suatu kewajiban yang berkaitan dengan kas dalam jangka pendek.

2. Analisis solvency dan long term debt (leverage) yang digunakan untuk menelaah struktur modal perusahaan yang termasuk sumber dana jangka panjang dan kemampuan suatu perusahaan dalam memenuhi kewajiban investasi dan utang jangka panjang.

3. Analisis aktivitas yang digunakan untuk mengevaluasi revenue dan output yang dihasilkan oleh aset perusahaan.

4. Analisis profitabilitas yang digunakan untuk mengukur earnings (laba) perusahaan relatif terhadap revenue (sales) dan modal yang diinvestasikan oleh perusahaan.

\section{Current rasio}

Current rasio merupakan rasio likuiditas (liquidity ratio) menggambarkan kemampuan kemampuan perusahaan memenuhi kewajiban jangka pendeknya yang telah jatuh tempo. Current ratio sendiri merupakan salah satu indikator dari 
rasio likuiditas. CR merupakan rasio antara lancar dengan hutang lancar yang dimiliki oleh perusahaan. rasio ini mengukur aktiva yang dimiliki perusahaan dalam hutang lancar perusahaan. Perusahaan dapat mengalami kesulitan keuangan baik dimulai dari yang sifatnya ringan (kesulitan likuiditas) sampai kesulitan keuangan baik dimulai dari yang sifatnya parah (kesulitan solvabilitas). Sedangkan menurut Weston dalam Zainudin dan Jogiyanto H. (1999) bahwa $\mathrm{CR}$ digunakan untuk mengukur penyelesaian jangka pendek. Sejauh mana tagihan kreditur jangka pendek dapat dipenuhi oleh aktiva yang diharapkan dapat dikonversi ke kas dalam jangka waktu yang kira-kira sama dengan jatuh tempo tagihan. Current yang terlalu tinggi menunjukkan kelebihan uang kas atau aktiva lancar lainnya di bandingkan dengan yang dibutuhkan sekarang.

\section{Debt to Equity Ratio}

Debt to equity ratio mencerminkan kemampuan perusahaan dalam memenuhi seluruh kewajibannya, yang ditunjukkan oleh berapa bagian modal sendiri yang digunakan untuk membayar hutang.
Myers dan Majluf dalam Prihantoro, (2003) dalam menghubungkan profitabilitas dengan kebijakan debt lewat sebuah hipotesis "pecking order" yang dimodifikasi, ditunjukan bahwa perusahaan-perusahaan yang lebih profitable akan menurunkan permintaannya akan debt, karena akan tersedia lebih banyak dana-dana internal untuk mendanai investasi.

Debt to Asset Ratio (DAR)

Debt to Asset Ratio (DAR) dapat diartikan sebagai besarnya aktiva perusahaan yang didanai dengan pendanaan dari pihak luar. Namun penggunaan dana dari pihak luar akan memperbesar resiko atas hasil (risk of return) bagi para pemegang saham karena adanya beban tetap pembayaran bunga pinjaman.

Penggunaan hutang yang semakin besar oleh pemilik modal sendiri dilihat sebagai peningkatan resiko perusahaan, artinya apabila perusahaan menggunakan hutang yang lebih besar, maka pemegang saham akan memperoleh pembagian laba yang semakin kecil.

Perusahaan yang menggunakan sumber dana dengan beban tetap dikatakan bahwa perusahaan tersebut 
mempunyai Debt to Asset Ratio (DAR). Tujuan penggunaan Debt to Asset Ratio (DAR)adalah agar terjadi perubahan laba per lembar saham biasa yang lebih besar atau adanya peningkatan kesejahteraan bagi pemegang saham.

\section{Net Profit Margin}

Margin laba bersih merupakan ukuran keuntungan dengan membandingkan antara laba setelah bunga dan pajak dibandingkan dengan penjualan. Rasio ini menunjukkan pendapatan bersih perusahaan penjualan.

\section{Quick Asset to Inventory (QAI)}

QAI merupakan salah satu rasio aktivitas (produktifitas) yang menunjukkan kemampuan perusahaan dalam menghasilkan aktiva lancar (terutama dalam bentuk kas) dari perputaran persediaan, semakin cepat perputaran inventory atau persediaan, menunjukkan semakin produktif perusahaan dalam menghasilkan aktiva lancar.

\section{Total Assets Turnover}

Merupakan rasio aktivitas yang digunakan untuk mengukur sampai seberapa besar efektivitas perusahaan dalam menggunakan sumber dayanya yang berupa asset. Semakin tinggi rasio ini semakin efisien penggunaan asset dan semakin cepat pengembalian dana dalam bentuk kas (Abdul Halim, 2007). Total Assets Turnover sendiri merupakan rasio antara penjualan dengan total aktiva yang mengukur efisiensi penggunaan aktiva secara keseluruhan. Apabila rasio rendah itu merupakan indikasi bahwa perusahaan tidak beroperasi pada volume yang memadai bagi kapasitas investasinya. Sedangkan menurut Weston dan Brigham (1989), TAT merupakan rasio pongelolaan aktiva terakhir, mengukur perputaran atau pemanfaatan dari semua aktiva perusahaan. Apabila perusahaan tidak menghasilkan volume usaha yang cukup untuk ukuran investasi sebesar total aktivanya, penjualan harus ditingakatkan. Beberapa aktiva harus dijual, atau gabungan dari langkahlangkah tersebut harus dilakukan.

\section{Return on Invesmen / Assets (ROI/ROA)}

Rasio ini adalah rasio keuntungan bersih setelah pajak terhadap jumlah asset secara keseluruhan. Rasio ini merupakan suatu ukuran untuk menilai seberapa besar tingkat pengembalian (\%) dari asset yang dimiliki. Apabila rasio ini tinggi berarti menujukkan 
adanya efisiensi yang dilakukan oleh pihak manejemen.

Rasio Return on Assets (ROA) mengukur kemampuan perusahaan menghasilkan laba bersih berdasarkan tingkat asset tertentu. Return on Asset (ROA) merupakan pengukuran kemampuan perusahaan secara keseluruhan di dalam menghasilkan keuntungan dengan jumlah keseluruhan aktiva yang tersedia di dalam perusahaan, semakin tinggi rasio ini berarti semakin baik keadaan suatu perusahaan.

\section{Return on equity (ROE)}

Hasil pengembalian ekuitas atau return on equity atau rentabilitas modal sendiri merupakan rasio untuk mengukur lalu bersih sesudah pajak dengan modal sendiri. Rasio ini menunjukkan efisiensi penggunaan modal sendiri. Semakin tinggi rasio ini, semaki baik. Artinya posisi pemilik perusahaan semakin kuat, demikian pula sebaliknya. Menurut Helfert (2000), Return on Equity (ROE) menjadi pusat perhatian para pemegang saham (stakeholders) karena berkaitan dengan modal saham yang diinvestasikan untuk dikelola pihak manajemen. ROE memiliki arti penting untuk menilai kinerja keuangan perusahaan dalam memenuhi harapan pemegang saham.

\section{Laba per lembar saham}

Rasio laba per lembar saham atau disebut juga rasio nilai buku merupakan rasio untuk mengukur keberhasilan manajemen dalam mencapai keuntungan bagi pemegang saham. Rasio yang rendah berarti manajemen belum berhasil untuk memuaskan pemegang saham, sebaliknya dengan rasio yang tinggi, kesejahteraan pemegang saham meningkat. Keuntungan bagi pemegang saham adalah jumlah keuntungan setelah dipotong pajak. Keuntungan yang tersedia bagi pemegang saham biasa adalah jumlah keuntungan dikurangi pajak, dividen, dan dikurangi hak-hak lain untuk pemegang saham prioritas.

\section{Kerangka Pemikiran}

Untuk memberikan gambaran yang jelas dalam penelitian ini diberikan kerangka pemikiran sebagai berikut:

Kabinet Indonesia Bersatu
Jilid I
X1 : CR
X2 : DER
X3 :LR
X4 : GPM
X5 : QAI
X6 : TAT
X7 : ROA

Kabinet Indonesia Bersatu Jilid II

$\mathrm{X} 1: \mathrm{CR}$

X2 : DER

$\mathrm{X} 3$ :LR

$\mathrm{X} 4: \mathrm{GPM}$

X5 : QAI

X6 : TAT

X7 : ROA

$\mathrm{X} 8$ : ROE 
Pengembangan Hipotesis

Dengan adanya Kabinet Indonesia Bersatu, pemerintah mengharapkan kinerja perpajakan akan semakin baik, sehingga dengan semakin membaiknya kinerja perusahaan. Kabinet Indonesia Bersatu, diharapkan akan memberikan dampak terhadap berbagai aspek yang ada di perusahaan dengan adanya pengeluaran modal, seperti motivasi manajer dan kebijakan perusahaan yang ada pada akhirnya meningkatkan kinerja mereka. Kinerja dari perusahaan mungkin dapat diamati dari keefisienan. Dengan demikian diperlukan penelitian lebih lanjut tentang kinerja perusahaan pada masa pemerintahan KIB I dan KIB II. Berdasarkan uraian diatas dapat dirumuskan hipotesis sebagai berikut :
H1 : Terdapat perbedaan Current Ratio (CR), Debt to Equity Ratio (DER), Debt to Asset Ratio (DAR), Gross Profit Margin (GPM), Operating Profit Margin (OPM), Net Profit Margin (NPM), Quick Asset to Inventory (QAI), Total Asset Turnover (TAT), Return on Asset (ROA), Return on Equity (ROE), dan Earning per Share (EPS) pada perusahaan makanan dan minuman di BEI pada masa Kabinet Indonesia Bersatu I dan II.

\section{METODE PENELITIAN}

\section{Populasi dan Sampel}

Populasi dalam penelitian ini adalah perusahaan manufaktur. Sampel data studi ini terdiri perusahaan makanan dan minuman yang terdaftar di Bursa 
Efek Indonesia di periode 2004-2012 yaitu pada masa kabinet Indonesia Bersatu dengan pengambilan sampel melalui teknik Purposive Sampling. Purposive sampling adalah teknik penentuan sampel berdasarkan pertimbangan tertentu (Sugiyono, 2002), adapun kriteria tersebut sebagai berikut :

1. Perusahaan makanan dan minuman yang telah listing di BEI sampai tahun 2012

2. Tersedia laporan keuangan dari tahun 2004-2012

3. Perusahaan menerbitkan laporan keuangan yang mempunyai tahun buku berakhir 31 Desember. Hal ini untuk menghindari adanya pengaruh waktu partial dalam penghitungan rasio keuangan.

4. Periode dalam penelitian ini diambil waktu pelaksanaan kerja Kabinet yaitu KIB Jilid I : 2005 - 2008 dan KBI Jilid II : 2010 - 2013, hal itu dikarenakan pada tahun pertama masa pemerintahan, masa kerjanya masih bercampur dengan kabinet yang lama, sedangkan pada tahun terakhir masa pemerintahan dikarenakan tidak sepenuhnya selesai pada tahun tersebut.
5. Tersedia catatan atas laporan keuangan yang mendukung variabel penelitian

6. Penutupan harga saham pertahun selama periode pengamatan yaitu dari tahun 2004-2012.

\section{Jenis dan Sumber Data}

Data merupakan keterangan yang dapat memberikan gambaran tentang suatu keadaan. Data yang digunakan dalam penelitian ini berupa data sekunder, yaitu data kuantitatif yang berupa laporan tahunan yang dikeluarkan oleh perusahaan manufaktur yang terdaftar di Bursa Efek Indonesia dari tahun 2004 sampai dengan tahun 2012. Laporan keuangan tersebut diperoleh dari pojok Bursa Efek Indonesia (BEI) yang berada di Fakultas Ekonomi Universitas Sebelas Maret dan www.IDX.co.id serta laporan keuangan.

\section{Metode Pengumpulan Data}

Pengumpulan data dilakukan melalui metode dokumentasi, yaitu agar diperoleh data yang relevan, dapat dipercaya, obyektif dan dapat dijadikan landasan dalam proses analisis. Prosedur pengumpulan data melalui metode dokumentasi digunakan untuk memperoleh data-data laporan keuangan dan harga saham, dengan pooling data 
perusahaan manufaktur dari tahun 2006 sampai dengan tahun 2012.

\section{Definisi Operasional Variabel}

\section{Current rasio}

Current ratio merupakan ukuran yang digunakan untuk mengetahui kesanggupan memenuhi kewajiban jangka pendek, karena rasio tersebut menunjukkan seberapa jauh tuntutan dari kreditur jangka pendek dipenuhi oleh aktiva yang diperkirakan menjadi uang tunai dalam periode yang sama dengan jatuh tempo. Menurut Machfoedz, (1994) dapat dirumuskan sebagai berikut:

Current Ratio $=\frac{\text { Aktiva lancar }}{\text { Utang lancar }}$

\section{Debt to Equity Ratio}

Debt to equity ratio mencerminkan kemampuan perusahaan dalam memenuhi seluruh kewajibannya, yang ditunjukkan oleh berapa bagian modal sendiri yang digunakan untuk membayar hutang. Menurut Machfoedz (1994) debt to equity ratio (DER) dapat dirumuskan sebagai berikut:

Debt to Equity Ratio $=\frac{\text { Total hutang }}{\text { Modal Sendiri }}$

\section{Debt to Asset Ratio}

Debt to Asset Ratio (DAR) dapat diartikan sebagai besarnya aktiva perusahaan yang didanai dengan pendanaan dari pihak luar. Namun penggunaan dana dari pihak luar akan memperbesar resiko atas hasil (risk of return) bagi para pemegang saham karena adanya beban tetap pembayaran bunga pinjaman. Menurut Machfoedz (1994) Leverage dapat dirumuskan sebagai berikut

$$
\text { Debt to Asset Ratio }=\frac{\text { Total hutang }}{\text { Total Asset }}
$$

\section{Net Profit Margin}

Margin laba bersih merupakan ukuran keuntungan dengan membandingkan antara laba setelah bunga dan pajak dibandingkan dengan penjualan. Rasio ini menunjukkan pendapatan bersih perusahaan penjualan.

\section{Quick Asset to Inventory (QAI)}

QAI merupakan salah satu rasio aktivitas (produktifitas) yang menunjukkan kemampuan perusahaan dalam menghasilkan aktiva lancar (terutama dalam bentuk kas) dari perputaran persediaan, semakin cepat perputaran inventory atau persediaan, menunjukkan semakin produktif perusahaan dalam menghasilkan aktiva lancar. Menurut Machfoedz (1994) QAI dapat dirumuskan sebagai berikut:

$$
\mathrm{Q} A I=\frac{\text { Asset }}{\text { Inventory }}
$$

\section{Total Assets Turnover}

Merupakan rasio aktivitas yang digunakan untuk mengukur sampai seberapa besar efektivitas perusahaan 
dalam menggunakan sumber dayanya yang berupa asset.

$$
\text { Total Asset Turnover }=\frac{\text { Total Penjualan }}{\text { Total Aset }}
$$

\section{Return on Invesmen / Assets (ROI/ROA)}

Rasio Return on Assets (ROA) mengukur kemampuan perusahaan menghasilkan laba bersih berdasarkan tingkat asset tertentu. Return on Asset (ROA) merupakan pengukuran kemampuan perusahaan secara keseluruhan di dalam menghasilkan keuntungan dengan jumlah keseluruhan aktiva yang tersedia di dalam perusahaan, semakin tinggi rasio ini berarti semakin baik keadaan suatu perusahaan. Ukuran yang sering digunakan untuk menghitungReturn on Assets (ROA) adalah :

$$
\text { ROA }=\frac{\text { Laba setelah pajak }}{\text { TotalAsset }}
$$

\section{Return on equity (ROE)}

Return on Equity (ROE) menjadi pusat perhatian para pemegang saham (stakeholders) karena berkaitan dengan modal saham yang diinvestasikan untuk dikelola pihak manajemen. ROE memiliki arti penting untuk menilai kinerja keuangan perusahaan dalam memenuhi harapan pemegang saham.

\section{Laba per lembar saham}

Rasio laba per lembar saham atau disebut juga rasio nilai buku merupakan rasio untuk mengukur keberhasilan manajemen dalam mencapai keuntungan bagi pemegang saham. Rumus untuk mencari laba per lembar saham biasa adalah sebagai berikut:

Earningpershare $=\frac{\text { Laba bersih setelah bunga dan pajak }}{\text { Jumlahsaham yang beredar }}$

\section{Analisa Data}

Metode Analisis data yang digunakan dalam penelitian ini adalah (Husein Umar, 1999, 29) :

\section{Analisis Deskriptif}

Analisis statistik deskriptif digunakan untuk memberikan gambaran mengenai variabel-variabel penelitian ini dengan menggunakan tabel distribusi frekuensi absolute yang menunjukkan angka rata-rata, media kisaran dan deviasi standar.

\section{Normalitas}

Normalitas adalah kewajaran distribusi data mempunyai distribusi normal atau tidak (Gozhali, 2005). Untuk menguji apakah distribusi normal atau tidak dapat dilakukan dengan cara melihat uji Kolmogorov Smirnov. Data berdistribusi normal 
apabila signifikansinya lebih besar dari 0,05 .

3. Uji Hipotesis

Pengujian hipotesis dilakukan untuk menguji adanya perbedaan kinerja keuangan pada perusahaan manufaktur yang go public di BEI sebelum dan sesudah diberlakukannya Undang-Undang Perpajakan Tahun 2008 . Pengujian hipotesis yang digunakan yaitu Paired sampel T-test yang dengan menggunakan program SPSS. Dasar pengambilan keputusan pada uji t : a. Jika signifikansi pengujian lebih kecil dari 0,05 maka terdapat perbedaan kinerja keuangan pada perusahaan manufaktur yang go public di BEI sebelum dan sesudah diberlakukannya Undang-Undang Perpajakan Tahun 2008.

b. Jika signifikansi pengujian lebih besar dari 0,05 maka tidak terdapat perbedaan kinerja keuangan pada perusahaan manufaktur yang go public di BEI sebelum dan sesudah diberlakukannya Undang-Undang Perpajakan Tahun 2008.

\section{Pembahasan}

\section{Tabel 1 Data sampel}

\section{Kriteria}

Perusahaan makanan dan minuman yang terdaftar di Bursa Efek Indonesia selama periode penelitian Jumlah perusahaan yang tidak menyampaikan laporan tahunan selama 3 tahun berturut-turut Jumlah sampel penelitian selama 1 periode Jumlah sampel penelitian (4x17)

Sumber: data yang diolah

Perusahaan-perusahaan yang tersebut disajikan seperti dalam tabel 2 memenuhi persyaratan sebagai sampel sebagai berikut:

Tabel 2. Daftar Sampel Perusahaan Manufaktur

\begin{tabular}{clc}
\hline NO & \multicolumn{1}{c}{ Nama Perusahaan } & KODE \\
\hline 1 & Akasha Wira International Tbk & ADES \\
2 & PT Tiga Pilar Sejahtera Tbk & AISA \\
3 & PT Cahaya Kalbar Tbk & CEKA \\
4 & PT Davomas Abadi Tbk & DAVO \\
5 & PT Delta Djakarta Tbk & DLTA \\
6 & PT Fast Food Indonesia & FAST \\
7 & PT Indofood Sukses Makmur Tbk & INDF \\
8 & PT Multi Bintang Indonesia Tbk & MLBI \\
\hline
\end{tabular}




\begin{tabular}{clc}
\hline 9 & PT Mayora Indah Tbk & MYOR \\
10 & PT Prasidha Aneka Niaga Tbk & PSDN \\
11 & PT Pioneerindo Gourmet International Tbk & PTSP \\
12 & Sierad Produce Tbk. & SIPD \\
13 & PT Sekar Laut Tbk & SKLT \\
14 & SMART Tbk. & SMAR \\
15 & PT Siantar Top Tbk & STTP \\
16 & Tunas Baru Lampung Tbk. & TBLA \\
17 & PT Ultrajaya Milk Industry \& Trading Company Tbk & ULTJ \\
\hline
\end{tabular}

Sumber: data diolah

\section{Analisis Uji Normalitas}

Pengujian normalitas data dilakukan dengan menggunakan metode One-Sample Kolmogorov-Smirnov Test sebagai prasyarat pengujian perbedaan dua rata-rata dari kelompok observasi berpasangan. Jika data tidak normal, ada beberapa cara mengubah model regresi menjadi normal yaitu:

1. Lakukan transformasi data, misalnya mengubah data menjadi bentuk Logaritma (Log) atau natural (Ln).

2. Menambah jumlah data.

3. Menghilangkan data yang dianggap sebagai penyebab tidak normalnya data.

4. Menerima data apa adanya.

Untuk menghindari/ mengatasi terjadinya data yang tidak normal, maka peneliti mentransform data ke logaritma (Ghozali, 2005).

Data yang berdistribusi normal dengan nilai signifikasi 2 tailed lebih besar dari $\alpha=5 \%$ atau 0,05 maka digunakan uji t-test paried two sample for means atau paired samples $t$ test. Berdasarkan Pengujian normalitas data menggunakan uji Kolmogorov-Smirnov menunjukan bahwa:

Tabel 3 Hasil Uji Normalitas Data

\begin{tabular}{lcclcc}
\hline & $\begin{array}{c}\text { Kolmogorov- } \\
\text { Smirnov Z }\end{array}$ & $\begin{array}{c}\text { Asymp. } \\
\text { Sig. }\end{array}$ & $\begin{array}{c}\text { Kolmogorov- } \\
\text { Smirnov Z }\end{array}$ & $\begin{array}{c}\text { Asymp. } \\
\text { Sig. }\end{array}$ \\
\hline CR KIB 1 & 0,827 & 0,501 & QAI KIB 1 & 0,753 & 0,622 \\
CR KIB 2 & 0,600 & 0,366 & QAI KIB 2 & 0,836 & 0,487 \\
DER KIB 1 & 1,341 & 0,055 & TAT KIB 1 & 1,096 & 0,181 \\
DER KIB 2 & 0,703 & 0,707 & TAT KIB 2 & 0,850 & 0,466 \\
DAR KIB 1 & 1,112 & 0,169 & ROA KIB 1 & 1,345 & 0,054 \\
DAR KIB 2 & 1,282 & 0,075 & ROA KIB 2 & 0,728 & 0,664 \\
NPM KIB 1 & 0,956 & 0,320 & ROE KIB 1 & 0,987 & 0,284 \\
NPM KIB 2 & 1,105 & 0,174 & ROE KIB 2 & 0,659 & 0,779 \\
\hline
\end{tabular}




\begin{tabular}{llllll}
\hline EPS KIB 1 & 0,696 & 0,717 & EPS KIB 2 & 0,688 & 0,731 \\
\hline
\end{tabular}

Sumber: data yang diolah

Nilai z Kolmogorov-Smirnov $C R$ sebelum dan sesudah reformasi pajak memiliki nilai

\section{Pengujian Hipotesis}

Uji hipotesis dilakukan dengan uji analisis uji t-test paired two sample for means atau uji Paired Samples T Test signifikansi diatas $5 \%$ sehingga data residual berdistribusi normal.

Tabel 4. Hasil Uji Beda Kinerja Perusahaan pada KIB I dan KIB II

\begin{tabular}{llccc}
\hline & & t & df & sih \\
\hline Pair 1 & CR KIB I - CR KIB II & $-2,807$ & 67 & 0,007 \\
Pair 2 & DER KIB II - DER KIB I & 3,863 & 67 & 0,000 \\
Pair 3 & DAR KIB I - DAR KIB II & 1,841 & 67 & 0,070 \\
Pair 4 & NPM KIB I - NPM KIB II & $-3,093$ & 67 & 0,003 \\
Pair 5 & QAI KIB I - QAI KIB II & 0,791 & 67 & 0,432 \\
Pair 6 & TAT KIB I - TAT KIB II & 1,696 & 67 & 0,095 \\
Pair 7 & ROA KIB I - ROA KIB II & $-2,815$ & 67 & 0,007 \\
Pair 8 & ROE KIB I - ROE KIB II & $-1,093$ & 67 & 0,279 \\
Pair 9 & EPS KIB I - EPS KIB II & $-4,688$ & 67 & 0,000 \\
\hline
\end{tabular}

Sumber: data yang diolah

Berdasarkan tabel 4 menunjukkan bahwa variabel yang signifikan pada level 5\% adalah CR, DER, NPM, ROA dan EPS. Tidak terdapat perbedaan yang signifikan untuk variabel QAI, TAT, dan ROE perusahaan makanan dan minuman pada periode KIB I dan KIB II. Dari hasil tersebut dapat ditarik kesimpulan bahwa perbedaan yang signifikan pada CR, nya.

\section{Kesimpulan}

karena data berdistribusi normal dengan sampel berhubungan (Related samples). Perumusan uji hipotesis dalam penelitian ini adalah sebagai berikut: 
Untuk meraih profit yang diharapkan, maka efisiensi mutlak harus dilakukan oleh setiap perusahaan, tidak terkecuali perusahaan dagang dalam rangka menjaga kelangsungan usaha maupun meningkatkan daya saing. Secara umum kegiatan perdagangan di Indonesia menunjukkan perkembangan yang baik, hal tersebut tercermin melalui peningkatan volume usaha, investasi dan peningkatan efisiensi investasi. Berdasarkan pembahasan dan analisis yang dijelaskan pada bab - bab sebelumnya, maka pada penelitian ini dapat disimpulkan bahwa kinerja perusahaan makanan dan minuman pada periode KIB I dan KIB II:

1. Terdapat perbedaan yang signifikan untuk variabel CR, DER, NPM, ROA dan EPS, perusahaan makanan dan minuman pada periode KIB I dan KIB II, hal ini berarti bahwa pengelola perusahaan dan investor secara umum merespon pada periode pemerintahan KIB I dan KIB II.

2. Tidak terdapat perbedaan yang signifikan untuk QAI, TAT, dan ROE perusahaan makanan dan minuman pada periode KIB I dan KIB II, hal ini berarti perusahaan belum memanfaatkan aktiva yang dimilikinya untuk menghasilkan keuntungan pada periode pemerintahan KIB I dan KIB II.

\section{Saran}

Berdasarkan penelitian yang telah dilakukan, maka peneliti memberikan saran sebagai berikut :

1. Untuk masa pemerintahan Kabinet Kerja pada masa Presiden Joko Widodo, maka sudah selayaknya bila perusahaan harus selalu mendapatkan perhatian yang serius dari pemerintah. Kebijakan-kebijakan yang terkait dengan perusahaan harus mempertimbangkan dampaknya bagi dunia usaha, yaitu meningkatkan kinerja keuangan perusahaan. Penelitian ini diharapkan memberikan fasilitas-fasilitas yang diberikan pemerintah mengenai sasarannya. Sehingga pengorbanan yang berupa program kerja kabinet dapat menjadi pendorong bagi perekonomian, baik dalam jangka pendek maupun jangka panjang.

2. Bagi investor, sebaiknya mempertimbangkan terlebih dahulu apakah keputusan melakukan investasi benar-benar kebijakan yang tepat yang dapat mempengaruhi laba dengan baik ataukah tidak karena 
kebijakan investasi akan berpengaruh pada masa Pemerintahan Presiden Jokowi Wdodo

3. Bagi perusahaan hendaknya perusahaan meningkatkan kinerja keuangan perusahaan sehingga dapat menarik investor untuk berinvestasi pada perusahaan mereka pada masa pemerintahan selanjutnya, yang diharapkan dapat memberikan kebijakan-kebijkan yang berguna bagi perusahaan.

4. Sampel yang digunakan seharusnya tidak hanya dari jenis perusahaan makanan dan minuman yang terdaftar di Bursa Efek Indonesia tetapi berasal dari semua jenis perusahaan agar

DAFTAR PUSTAKA

Ang, Robert. 1997. Pasar Modal Indonesia. Media Soft Indonesia.

Bambang, Riyanto, 2001. Dasar-Dasar Pembelanjaan Perusahaan, Edisi. Keempat, Cetakan Ketujuh, BPFE Yogyakarta

Ghozali, Imam. 2005. Aplikasi Analisis Multivariate dengan program SPSS edisi 3. Semarang: Fakultas Ekonomi Universitas Diponegoro.

Halim, Abdul. 2007. Akuntansi Keuangan Daerah. Jakarta: Salemba Empat.

Helfert, Erich A. 2000. Technics of Financial Analysis: A Guide to dapat membandingkan antar jenis perusahaan di segala bidang.

5. Penelitian selanjutnya diharapkan peneliti dapat menguji variabelvariabel lain yang dipengaruhi kinerja seperti volume perdagangan saham dan abnormal return untuk memperjelas pembuktian teori sehingga akan membuat penelitian yang akan datang menjadi lebih baik.

6. Memperpanjang jangka waktu pengamatan sehingga dapat memberi hasil yang lebih akurat mengenai pengaruh perubahan peraturan perpajakan kedepannya terhadap tingkat efisiensi perusahaan.

Value Creation. 10th Edition. Singapore : McGraw-Hill Book Co.

Machfoedz, Mas'ud. 1994. Financial Ratio Analysis and The Prediction of Earnings Changes in Indonesia. Yogyakarta: Gajah Mada University Business Review, No.7/III.

Mariwan, Arifin. 2005. Analisis Kinerja Keuangan dan Penerimaan Pajak Penghasilan Badan Usaha Pada Periode Sebelum dan Setelah Reformasi Pajak Tahun 2000 (Studi Kasus Pada Badan Usaha diWilayah Kabupaten Sleman, Kulonprogo dan Gunungkidul). Sinergi ISSN 1410-1918. 
Munawir. 2002. Akuntansi Keuangan Dan Manajemen. Edisi Revisi. Penerbit BPFE. Yogyakarta.

Prihantoro. 2003. Estimasi Pengaruh Dividend Payout Ratio pada Perusahaan Publik di Indonesia. Jurnal Ekonomi \& Bisnis. Vol. 8 No. 1.

Sugiyono. 2002. Statistik Untuk Penelitian. Bandung: CV. Alfabeta.
White G.I., Ashwinpaul C. Sondhi dan Dov Fried. 2003. The Analysis and Use of Financial Statements. USA: John Wiley. pg. 119-135

Zainuddin dan Jogianto Hartono. 1999. Manfaat Rasio Keuangan dalam Memprediksi Pertumbuhan Laba: Suatu Studi Empiris pada Perusahaan Perbankan yang Terdaftar di Bursa Efek Jakarta. Jurnal Riset Akuntansi Indonesia Vol.2 No.1. 